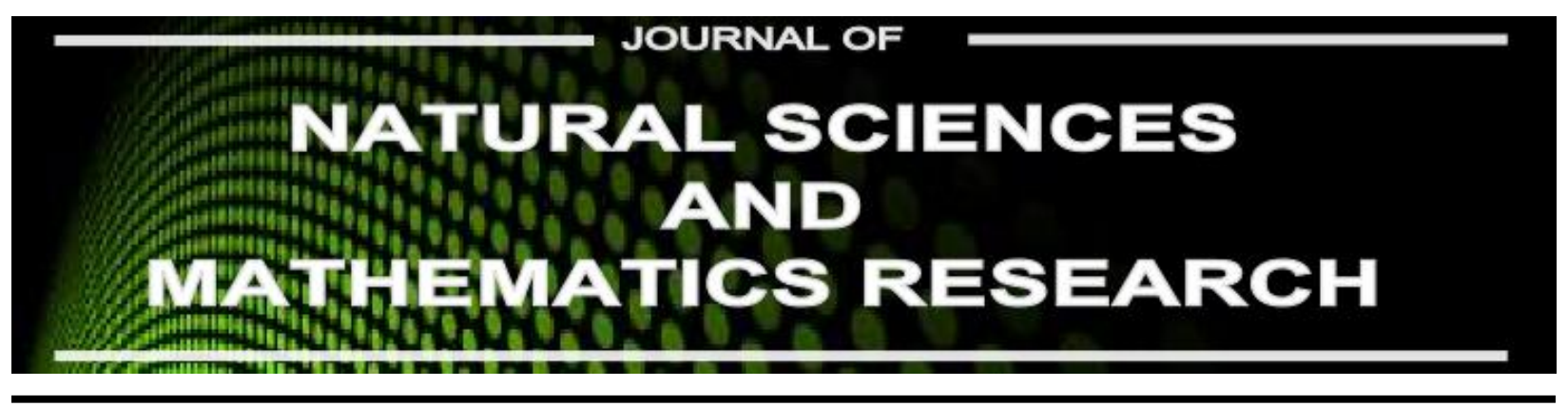

Available online at http://journal.walisongo.ac.id/index.php/jnsmr

\title{
Synthesis and Characterization of Cassava Shell Based Biodegradable Plastic with Kitosan Addition
}

\author{
Supriyono ${ }^{1}$, Hamdan Hadi Kusuma1, Mulyatun ${ }^{2}$, and Biaunik Niski Kumila ${ }^{3}$ \\ ${ }^{1}$ Department of Physics Education, Faculty of Science and Technology, Wallisongo State Islamic University \\ ${ }^{2}$ Department of Chemistry Education, Faculty of Science and Technology, Wallisongo State Islamic University \\ ${ }^{3}$ Department of Physics, Faculty of Science and Technology, Wallisongo State Islamic University
}

\begin{abstract}
Corresponding author: coesma@yahoo.com Recived: 18 April 2017, Revised : 20 May 2017 Accepted: 20 June 2017.

Wasted-plastic which is a hardly-decomposed material was one of the major problems of trash-recycling management in Indonesia. Replacing a common plastic with biodegradable plastic was one of the solution to reduce the amount of undecomposed-materials in the enviroment. Therefore, the aim of this resarch is to study how to synthesis cassava shell based biodegradable plastic and to analyse the effect of kitosan addition on cassava shell based biodegradable plastic properties. There are three basic characterization processes performed to analyse the sample properties, i.e mechanical test, FTIR and biodegradability test. Kitosan enhanced the mechanical and biodegradability properties of samples. The elongation-percentage decreased down to $8,57 \%$ along with the increasing the amount of kitosan concentration. FTIR data indicated the presence of $\mathrm{O}-\mathrm{H}, \mathrm{N}-\mathrm{H}, \mathrm{C}-\mathrm{H}, \mathrm{C}=\mathrm{C}, \mathrm{NO}_{2}$ and $\mathrm{C}-\mathrm{O}$ organic functional group on biodegradable plastic samples. Kitosan reduce the decomposition process of samples due to its hydrophilicity. Sample with highest concentration of kitosan decomposed at the longest time up to 14 days. . (C)2017 JNSMR UIN Walisongo. All rights reserved.
\end{abstract}

Key words: Palstic; Biodegradable; Citosan;

\section{Introduction}

The growth of plastic consumption caused many problems such as increasing the amount of undecomposed wasted-plastic in enviroment. The main plastic custumer is food and baverage company which its consumption is up to $60 \%$ [1]. Indonesian plastic consumption reached a number of $1700 \mathrm{~kg}$ per year with the consumption growth is up to 6-7 
$\%$ per year [2]. In 2013, Indonesian plastic demand increase to $22,58 \%$ compared to that of 2012, and the predicted demand is getting increased [1].

The best solution to diminish the amount of undecomposed wasted plastic is to develop such a enviromental-friendly-plastic, so called biodegradable plastic. Biodegradable plastic or bioplastic is mostly synthesized from biodegradable materials such as organic substance extract, cellulose, lignin, protein and lipid from animals and plants [3]. Due to its hydrophilicity, low cost and abundance, cassava shell extract was mostly employed as a base materials in biodegradable plastic synthesis [4].

The prominent materials in supporting plastic biodegradable synthesis is kitosan which possess anti-mikrobacterial property [5] and plasticizer which contribute to enhance flexibility and form plastic-like property [6].

Previous research showed that plasticizer addition enhanced the tensile strength and elongation [3] while the kitosan addition enhanced the mechanical property obtaining a robust and enviromental-friendly biodegradable plastic [5]. Kitosan contains amine and hydroxyl functional group which enhance the hydrophobicity and chemical reaction with other functional group. Kitosan is a kitin derivative, one of the most abundant polysaccharide in universe [7]. The chemical structure of kitosan is shown by Figure 1.

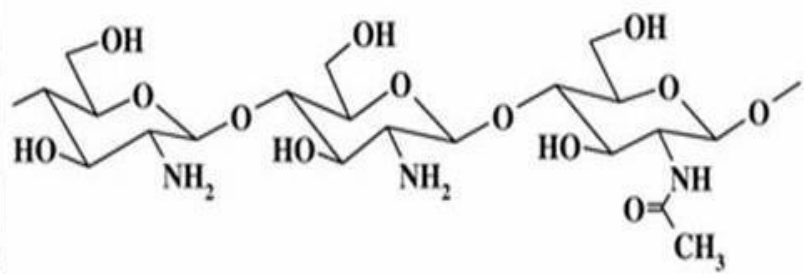

Figure 1. Chemical structure of Kitosan

This research observed the effect of varying kitosan concentration to biodegradable plastic properties.

\section{Experiments Procedure}

The research method is generally shown by Figure 2 .

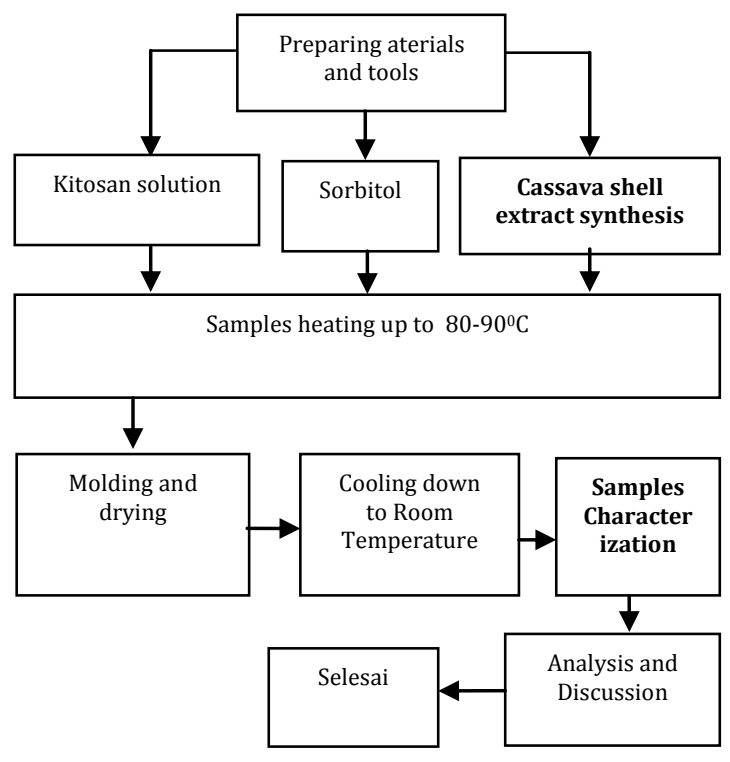

Figure 2. Scheme of Research Method

Cassava shell extract was obtained by several steps i.e peeling, immersing in calcium carbonate solution, shieving, filtering and drying. The dry extracted cassava shell is shown in Figure 3.

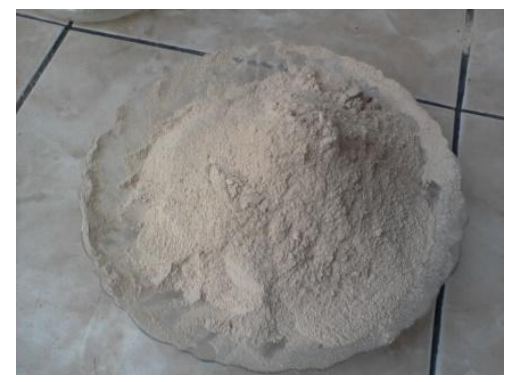

Figure 3. Dry extracted cassava shell powder

The sample powder was then diluted in 2 $\%$ acetic acid solution and DI water. Kitosan mass was varied to $1.5 \mathrm{gr}, 2 \mathrm{gr}, 2.5 \mathrm{gr}$ and $3 \mathrm{gr}$. The solution was then stirred for 15 minutes and heated up at temperature of $80^{\circ} \mathrm{C}-90^{\circ} \mathrm{C}$ to form a gel solution.

The gel solution was then molded and dried at temperature of $60^{\circ} \mathrm{Cfor} 7-8$ hours and chilled to room temperature for 6 hours. There 
are three main sample characterization performed in this research, i.e mechanical property test, Fourier Transform Infra-Red (FTIR) characterization and biodegradability test. Mechanical characterization was executed in Materials Engineering Laboratory, Faculty of Engineering, Gajah Mada University, Yogyakarta. FTIR characterization was executed in Organic Chemistry Laboratory, Faculty of Science and Mathematics, Gajah Mada University with the range of wavelength of $500-4000 \mathrm{~cm}^{-1}$. This test is to observe the functional group contained in the sample. The biodegradability test was performed in Chemistry Laboratory, Faculty of Science and Technology, UIN Walisongo with soil burial technique. The sample was burried in a soil and exposed to air. The biodegradability property is obtained from the percentage of loss mass after exposure to the air.

\section{Result and Discussion}

The effect of kitosan addition to the mechanical property is shown by Figure 7 .

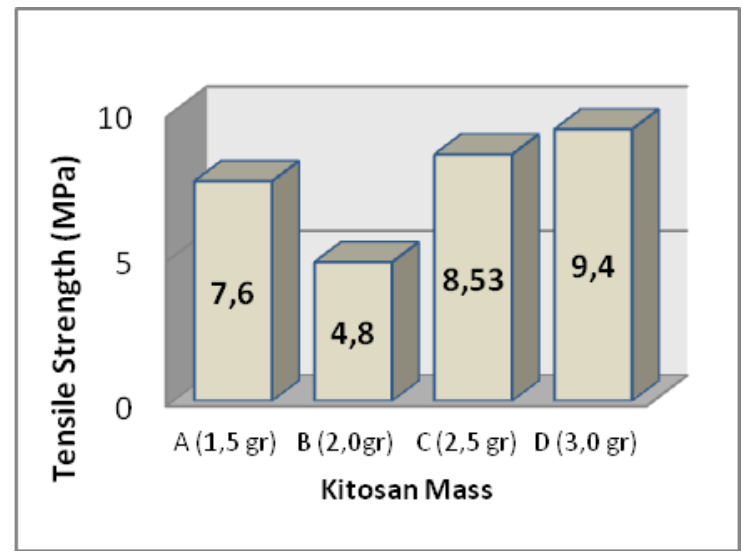

Figure 4. The influence of Kitosan to the Tensile Strength

Figure 4 shows that sample $B$ has the lowest tensile strength, i.e 4,8 Mpa and sample $\mathrm{D}$ has the highest tensile strength, i.e 9,4 Mpa. The kitosan addition enhance the tensile strength due to increasing the amount of hydrogen bond consisting in the sample which require higher amount of energy to break the bond [8]. Furthermore, the tensile strength of sample B is lower than sample A. This is due to non-optimal heating process on sample $\mathrm{B}$.

Materials with high tensile strength is mostly possessing a low elongation percentage. This is due the nature of a high tensile strength materials is hard to be strecthed. The elongation percentage is deminished along with the increasing kitosan concentration due to decreasing its intermolecular distance [9]. The effect of kitosan concentration on elongation percentage is shown by Figure 5 .

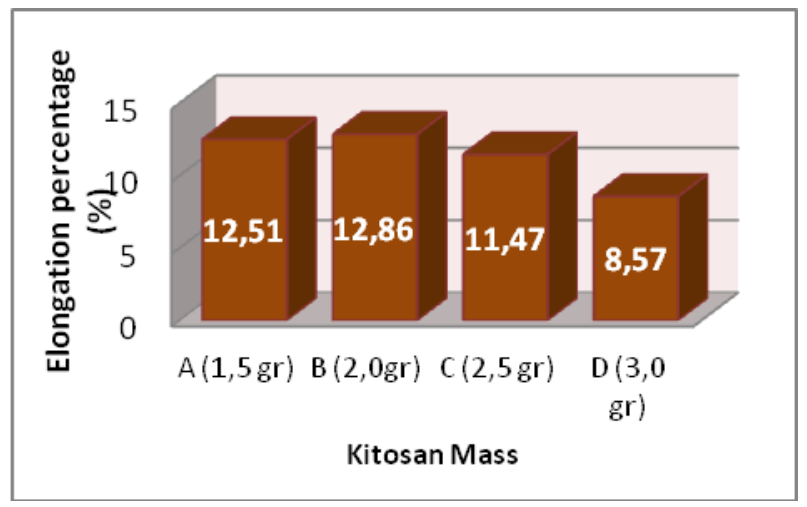

Figure 5. The effect of kitosan concentration on elongation percetage

Figure 5 shows that the elongation percentage is decreased along with the increasing kitosan concentration, except for sample B. The biodegradibility quality of samples was then compared to conventional plastic.

Tabel 1. The quality comparison of conventional plastic and biodegradable plastic

\begin{tabular}{llllll}
\hline & Con- & \multicolumn{5}{c}{ Biodegradable plastic } \\
\cline { 3 - 6 } & $\begin{array}{l}\text { vetional } \\
\text { plastic }\end{array}$ & $\mathrm{A}$ & $\mathrm{B}$ & $\mathrm{C}$ & $\mathrm{D}$ \\
\hline $\begin{array}{c}\text { Tensile } \\
\text { strength } \\
\text { (MPa) } \\
\%\end{array}$ & $24.7-302$ & 7,6 & 4,8 & 8.53 & 9.4 \\
$\begin{array}{c}\text { elongation } \\
\text { enganyyyy}\end{array}$ & $21-220$ & 12,51 & 12.86 & 11.47 & 8.57 \\
\hline
\end{tabular}

Table 3 conclude thatthe mechanical property of biodegradable plastic is still not as great as conventional plastic. 
Figure 6 shows that the Modulus Young is increasing along with the increasing kitosan mass contained in the samples, except for sample B. That is due to the incomplete heating process of sample $B$.

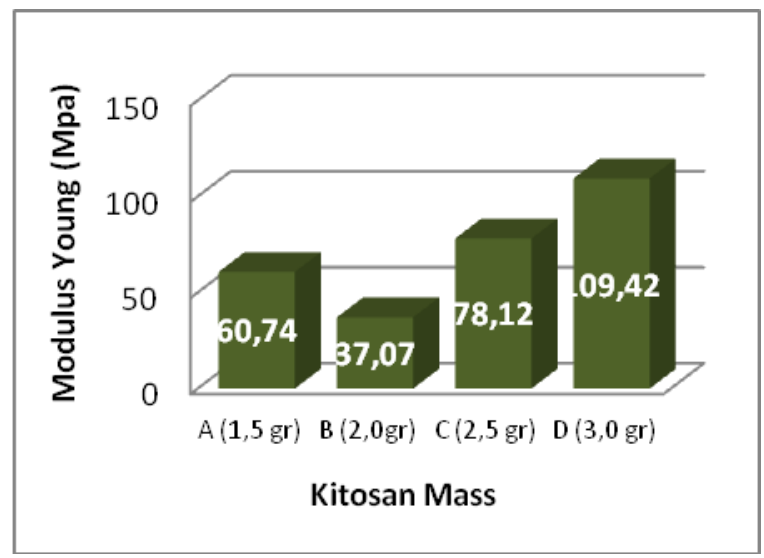

Figure 6. The Effect of Kitosan Mass Variation to Modulus Young of Biodegradable Plastic

In conclusion, the value of tensile strength is in agreement with that of modulus young. Those values are increasing along with the increasing kitosan mass on the sample. FTIR test is only applied on the sample possesing the highest tensile strength, i.e. sample D. FTIR data shows that the peak at $3433.29 \mathrm{~cm}^{-1}$ is assigned to $\mathrm{O}-\mathrm{H}$ functional group, $3873.06 \mathrm{~cm}^{-1}$ is assigned to $\mathrm{N}-\mathrm{H}$ secondary amine, 2924.09 $\mathrm{cm}^{-1}$ is assigned to $\mathrm{C}-\mathrm{H}$ alkana with low intensity, the high peak intensity at wave number of $1635.64 \mathrm{~cm}^{-1}$ is assigned to $\mathrm{C}=\mathrm{C}$, $1381,03 \mathrm{~cm}^{-1}$ is assigned to $\mathrm{NO}_{2}$ and 1026.13 $\mathrm{cm}^{-1}$ is assigned to $\mathrm{C}-\mathrm{O}$ functional group. Those functional groups is organic functional groups leading to the enviromental-friendly biodrgradable plastic [9].

Figure 7 shows that sample A was decomposed on the day-10, sample B was completely decomposed on the day-8, sample C was completely decomposed on the day- 12 and sample D was completely decomposed on the-day 14. Sample D with the highest amount of kitosan addition decomposed in the longest time. Kitosan is hydrophobic and being able to enhance the tensile strength of samples. Therefore, sample with the highest amount of kitosan addition require a longer time to be decomposed[10].

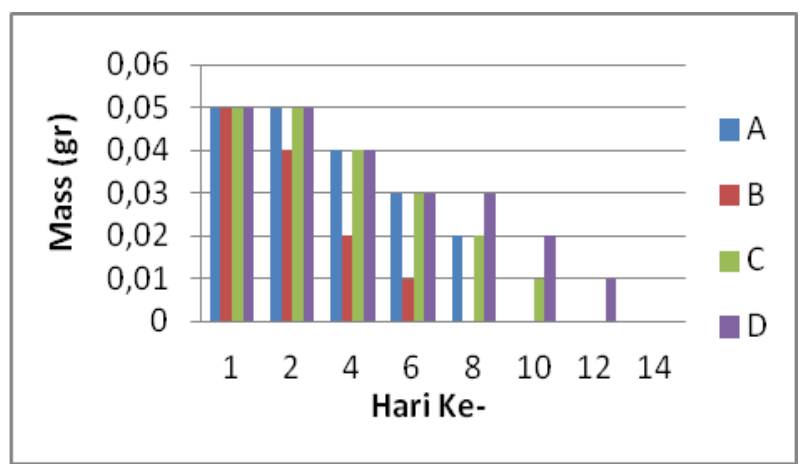

Figure 7. The plastic mass during biodegradability test for 14 days

\section{Conclusion}

The cassava shell based biodegradable plastic was successfully synthesized with kitosan addition. The kitosan addition enhance the mechanical property of samples. That is due to the high amount of hydrogen bond which require more energy to break the bond. The number of elongation percentage is in inverse to the number of the tensile strength. Kitosan is hydrophobic. Therefore, the biodegradable plastic is decomposed at longer time for the sample with the higher amount of kitosan concentration.

\section{Acknowledgment}

The authors wish to thank Department of Physics, Wallisongo State Islamic University for supporting this work

\section{References}

[1] D. Arinandha, "Wajah Industri Plastik Indonesia." [Online]. Available: http://www.kompasiana.com/dhitaarina nda/wajah-industri-plastik-indonesia 54f7c9b9a33311df1d8b4a18. [Accessed: 05-Nov-2015].

[2] M. Ramadhani, "LIPI Garap Sampah Plastik." [Online]. Available: http://lipi.go.id/lipimedia/single/LIPIGarap-Sampah-Plastik/15162. 
[3] Y. Darni and U. Fathonah, "Pembuatan Plastik Biodegradable Dari Campuran Pati Ubi Jalar (Ipomoea Batatas) Dan Selulosa Residu Rumput Laut (Eucheuma Spinossum) Dengan Gliserol Sebagai Plasticizer," in Seminar Nasional Hasil Riset dan Srandarisasi Industri: Hasil Riset Dan Standarisasi Industri Berbasis Agro Serta Implementasinya, 2011.

[4] D. P. Ajeng, "Pembuatan dan Karakterisasi Struktur Mikro dan Sifat Termal Film Plastik Berbahan Dasar Pati Biji Nangka (Artocarpus heterophyllus)," Universitas Negeri Semarang, 2013.

[5] Y. D. Hartatik and dkk, "Pengaruh Penambahan Kitosan Terhadap Sifat Mekanik Dan Biodegradable Bioplastik," Universitas Brawijaya, 2013.

[6] H. Mulyono, Kamus Kimia. Jakarta: Bumi Aksara, 2005.
[7] W. Setiani, "Preparasi dan Karakterisasi Edible Film dari Poliblend Pati SukunKitosan," Valensi, vol. 3, no. 2, p. 101, 2013.

[8] P. Coniwanti and dkk, "Pembuatan Film Plastik Biodegredabel Dari Pati Jagung Dengan Penambahan Kitosan dan Pemplastis Gliserol," J. Tek. Kim., vol. 20, no. 4, 2014.

[9] I. Indriyanto and dkk, "Karakteristik Plastic Biodegradable Pektin Lidah Buaya," Semarang, 2014.

[10]B. I. Hidayah and Dkk, "Pembuatan Biodegradable Film Dari Pati Biji Nangka (Artocarpus Hetrophyllus) Dengan Penambahan Kitosan," in Pembuatan Biodegradable Film Dari Pati Biji Nangka (Artocarpus Hetrophyllus) Dengan Penambahan Kitosan, 2015. 